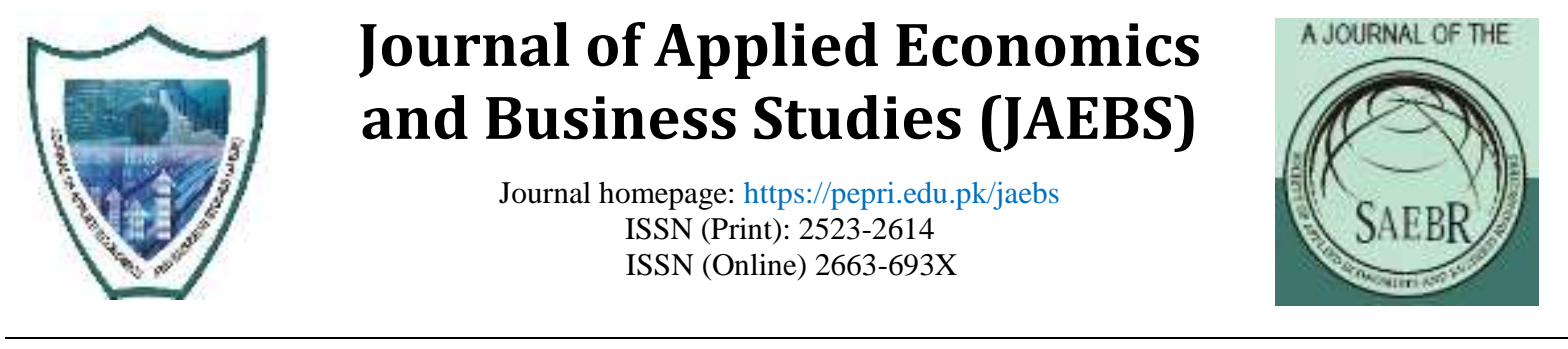

\title{
The Performance Effect of HPWS and Relational Coordination on Branch Efficiency: A Data Envelopment Analysis Approach
}

\author{
Muhammad Siddique $^{1 *}$, Zahoor Khan ${ }^{2} \&$ Saleem $_{\text {Gul }}{ }^{3}$ \\ ${ }^{1}$ Assistant Professor, Institute of Management Sciences, Peshawar \\ ${ }^{2}$ Assistant Professor, Institute of Management Sciences, Peshawar \\ ${ }^{3}$ Associate Professor, Institute of Management Sciences, Peshawar
}

\begin{abstract}
This study is set to analyse the role of high-performance work systems which is mainly aimed to boost knowledge, skills, and abilities of human resources in the form of effective communication and better coordination termed as relational coordination and subsequently improving performance. Using the theory of relational coordination that explains the relational aspects of coordination along with effective communication to influence performance outcomes, the study obtained data from 218 branches through survey focusing on employees' perspectives regarding high-performance work system in anticipating relational coordination among employees in performing focal work process of branch banking functions. The data obtained from officers was analysed through the Data Envelopment Analysis approach to identify efficient bank branches pivotal in formulating optimal policy measures. Results indicated that high-performance work systems envisaged relational coordination via the intervention of deposits and profitability. The findings contribute to the literature of high-performance work systems by indicating what interventions in high-performance work systems and the relational coordination may lead to bringing down operations cost or making improvements in the delivery of banking services. The study also implies that compared with managerial perspectives in the field, employees' perspectives provide significant insights about the relational process in explaining how a well-coordinated approach towards HR systems establish the social context for better HRM practices, enhancing.
\end{abstract}

Keywords

DEA, financial sector, HPWS, Organizational Performance, Pakistan, Relational Coordination.

JEL

Classification B26; D2; D21

\footnotetext{
*Email: muhammad.siddique@imsciences.edu.pk
} 


\section{Introduction}

Over the last few decades, there has been an increasing interest within management research in recognising the human factor in organizational performance. Organizations rely on various forms of resources to accomplish desired objectives, among other resources; human resources can accomplish a significant impact on firm performance. It is based on the premise that enhanced performance is mainly realized through the effective use of human resources in the organization (Nien-Chi \& Lin, 2019). The relationship between HRM and performance has been widely reported in the last few decades (e.g. Russell, et al., 2018; Ogbonnaya \& Valizade, 2018) as a large number of studies have reported significant associations between HR practices and performance (Delery \& Doty, 1996).

Recently, the focus is to examine not only the linkage between HR practices but also to explore the process through which human resource management influence performance. Researchers have suggested that to understand the relationship between human resource management practices and firm performance, there is a need to distinguish what constitutes as high-performance work systems (HPWS), the impact HRM practices as a system make on performance, and most importantly exploring the mechanism and process through which HRM practices make such impact on organizational performance.

The HPWS is generally understood to mean a set of HRM practices in the HRM literature (Methot, Rosado, \& Allen, 2018). Extensive research (e.g., Kehoe \& Collins, 2017; Zacharatos et al., 2005) has shown that studies have mostly adopted Pfeffer (1998) set of practices. These practices have received greater attention in the HPWS literature. These include practices that can improve the skills, knowledge, and abilities of employees, enhance their motivation, and can be helpful in the retention of competent employees while advocating poor performers to leave organization. The HR-performance link has been investigated from various perspectives rooted in organizational psychology, industrial relations, sociology and economics. Theories such as human capital, RBV of the firm, and the AMO framework provided support for understanding the HRM-performance link (Boselie, Dietz, \& Boon, 2005).

There is a large volume of studies describing the multidimensional nature of organizational performance (Boxall, 2012). The seminal work of Huselid' (1995) established empirical HRMperformance link, inspired a series of studies analysing the various form of performance such as economic gains, accounting income, customer satisfaction, and productivity (Paauwe, Wright, \& Guest, 2012). Across various sectors, there are different measures of organizational performance. The rationale for selecting certain indicators of performance largely depends on the objectives of the specific organization under study (Methot, Milwani, \& Rothman, 2017). Dyer and Reeves (1995) labelled performance outcomes into 4 categories including employee, financial, organizational, and market outcomes. 
Despite studies have reported that HPWS are positively associated with performance outcomes (e.g., Chao, \& Chih-Ting, 2018; Liao, Toya, Lepak, \& Hong, 2009), researchers have identified that earlier studies have paid little attention to the process linking HR practices to organizational performance (Boon, Den Hartog, \& Lepak, 2019; Malhotra \& Singh, 2016; Han, Bartol, \& Kim, 2015)

Previous studies have taken up different theories in examining the relationship between HRM practices with performance (Boselie et al., 2005). Using the concept of social capital, the relationships between employees have been theorised to act an important part in accomplishing high levels of performance (Havens, Gittell, \& Vasey, 2018). The theory of relational coordination as one of these relational perspectives describes specific dimensions of relationships that are essential to the coordination of work.

Relational coordination is considered a developing theory for distinguishing the dynamics of coordination work. The term relational coordination is generally understood to mean coordination of group members in the context of relationships in interdependent work setup (Gittell, 2001). According to Gittell (2002, p. 301) "relational coordination is a mutually reinforcing process of interaction between communication and relationship carried out for task integration". Relational coordination is an organised process that consists of communication and relationships. In addition to theoretical understanding, scholars have also suggested methodological gaps such as considering both managers' and employees' perceptions about HR practices will result in a better understanding of the HR-performance relationship (Wright \&Ulrich, 2017; Bowen \& Ostroff, 2004;). These issues imply that the process of linking highperformance work systems and performance is distant from complete hence, indicating a research gap (Fu, Bosak, Flood, \& Ma, 2019; Gerhart, 2012). Therefore, based in the theory of relational coordination, this study focuses on examining the links through which HPWS fosters relational coordination among employees and consequently influences organizational performance. The research questions are:

1. To what extent HPWS can influence the efficiency of unit-level performance in predicting relational coordination among employees.

2. To what degree the linkages between HPWS, Relational coordination, and performance is related to the ranking of efficient units.

This study used the above arguments to develop a research framework that incorporated the RC theory in HPWS-performance nexus, identifying relational coordination might help explain the process linking HPWS in positively influencing the efficiency of unit-level performance.

This study contributes to the multiple facets of HPWS and RC literature (concerning Pakistan). Firstly, the study used Data Envelopment Analysis (DEA) approach based on input 
and output models in which efficiency scores were calculated for three combinations. Firstly, to estimate the effects of HPWS in predicting relational coordination among employees (HPWS as input and relational coordination as output), secondly, to assess the relationship of HPWS with branch level performance outcomes (HPWS as inputs and performance outcomes as outputs), and thirdly, the effects of relational coordination on performance outcomes ( $\mathrm{RC}$ as inputs and performance as outputs). Thus, inputs for DMU's are divided into two main groups, i.e., HPWS \& Relational coordination. The variables under the umbrella of HPWS are JS, $\mathrm{T} \& \mathrm{D}$, employee participation, information sharing, job description, compensation, and appraisal.

The variables concerning Relational coordination are timely, frequent, accurate, problemsolving, communication, shared knowledge, shared goals, and mutual respect. In terms of output for each decision-making unit (branches as DMU's) are Deposits, advances, and profitability of 120 bank branches (see Table 1). The findings of DEA suggest that based on the combination of input-output models, certain branches were more efficient on HPWS in predicting relational coordination among employees. Secondly, some branches were highly efficient on HPWS concerning performance outcomes of deposits, advances, and profitability and many branches were efficient in terms of relational coordination and its influence on performance outcomes, which is in line with the literature (Gittell, Seidner \& Wimbush, 2010). Thirdly, it provides practical implications for policymakers suggesting the importance of employees' perspectives. Fourthly, the empirical evidence supports an important role of key stakeholders in designing HPWS frameworks, and increasing the input of relational coordination will further improve performance outcomes in terms of higher levels of deposits, performing loans, and profitability.

\section{Literature review}

HRM literature carries a consistent message that HR practices positively influence organizational performance (Murphy, Torres, Ingram, \& Hutchinson, 2018). In recent years, researchers have aimed at several other issues in HPWS. One of the major issues is related to the "black box" in HR literature (Sun, Xing, Yin, \& Yang, 2018; Boselie et al., 2005). To examine the black box, studies have focused on the role of HRM systems in affecting the attitude and behavior of employees (Mingqiong, Cherrie, Dowling, \& Bartram, 2013; Karadas \& Osman, 2019). For instance, Ostroff and Bowen (2000) viewed HR practices as critical elements in encouraging employees to behave in manners beneficial to organizational goals. Guest (1997) proposed that appropriate HR practices entice the commitment and motivation of employees that have a direct relationship with business results. In doing so, researchers have mainly relied on the resource-based view and AMO framework as theoretical foundations of the HPWS-performance relationship (Paauwe et al., 2012). 
Resource-Based View: The RBV approach proposes that firms pay greater attention to their resources for competitive advantage. Researchers have suggested that the RBV has significantly influenced the field of HRM and considered that a system of HR practices that are valuable in nature, rare, unique, and non-substitutable will lead to competitive advantage (Romanow, Rai, \& Keil, 2018). However, a number of studies have found that each HR practice prevailing in the organization cannot be a source of sustained competitive advantage (Meuer, 2017; Guest, 1997).

The AMO Framework: The AMO model (Appelbaum, Bailey, Berg, \& Kalleberg, 2000) has received more attention from the scholars for several reasons including its main components that enable employees to develop better skills, knowledge, and abilities along with motivation and get better opportunities about involvement in decision making.

\subsection{Relevance of relational coordination theory}

Several models explain the link between HPWS and performance (e.g. Guest, 1997; Appelbaum et al., 2000; Lee, Pak, Kim, \& Li, 2019). In view of Ostroff and Bowen (2000), most models are based on the assumption that superior HR practices are considered to result in more committed, motivated, and better-skilled employees, who, in turn, can be more productive to affect firm performance. So far, the most predominant arguments about causal mechanisms are based on employees' skills, abilities, motivation, human capital, and commitment. In addition to these arguments, there is a developing view that focuses on relationships between employees and considers it as an essential causal mechanism through which HPWS influence performance (Collins \& Smith, 2006). Therefore, in this study, a relational view is adopted and a model of HPWS has proposed in which each HR practice applies to multiple functions in an interdependent work setting.

Relational coordination distinguishes the relational dynamics of coordination work, which comprises communication and relationship aspects in the performance of the interdependent task (Siddique, Procter, \& Gittell, 2019; Gittell, 2002). Relational coordination theory assumes that HPWS is due to influence the performance outcomes through their effects on the degree of relational coordination. It suggests that because of social relationships and better information processing capacity, relational coordination is expected to result in better communication ties among employees with different expertise across functions. Relational coordination brings more consistency in communication that enables employees to reduce the number of errors and time wasted in searching misplaced information, carrying out unnecessary communication, and waiting for a response from other workers (Gittell et al., 2010).

Based on social capital, the relationships between employees have been understood to act an important role in accomplishing performance (Faraj \& Sproull, 2000; Adler, Kwon, \& Heckscher, 2008). In general, RC theory is exclusive in determining explicit dimensions of 
relationships that are essential to the coordination of job, precisely going ahead of shared knowledge to encompass mutual respect and shared goals, while concentrating on the improvement of these relationships between roles instead of between specific individuals. Relational coordination theory offers a particular approach to conceptualize the relational dynamics of coordination, their anticipated effects, and basic predictors. Therefore, this theory is applicable to work processes with a high level of interdependence involving multiple employees to carry out the tasks under uncertain circumstances and time restrictions (Gittell et al., 2010).

\subsection{Conceptual framework}

In this model, relationships among employees are considered as a link between HPWS and performance. This study recommends that HPWS is set for improving relational coordination, which is expected to build up branch-level performance. Based on the theory of relational coordination, HPWS affects relational coordination at the unit level, and relational coordination in turn is linked with the impact of HPWS on overall branch performance, indicating a relational process through which HPWS work.

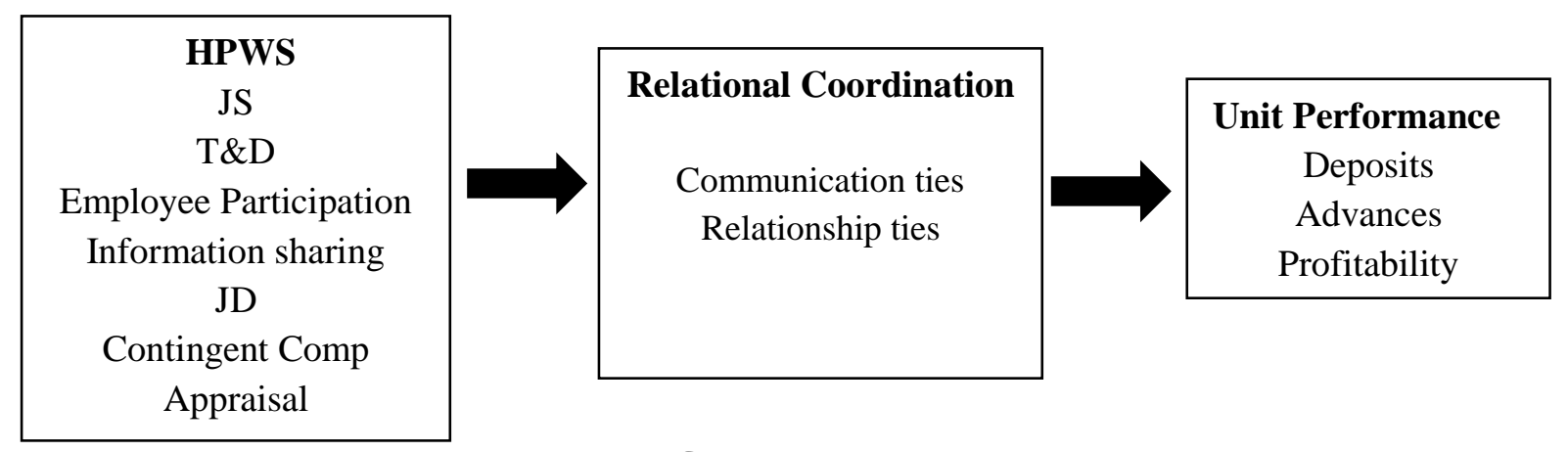

Figure 1: Conceptual framework

Source: The above theoretical framework is adopted form Gittell, Seidner \& Wimbush (2010).

\section{Methods}

\subsection{Research approach}

The study used a predictive research design. For this purpose, in the first stage, the information related to HPWS and RC was obtained from managerial and officer cadre employees working in various functions including operations, cash, and credit departments from 218 branches (Babbie, 2004). Secondly, data regarding branch-level performance outcomes including deposits advances, and profitability was gathered subsequently after the survey on completion of the financial year. Thirdly, based on the inputs and outputs of Decision-making Units (DMU's) efficiency and super-efficiency of DMU's were determined via Data Envelopment Analysis (DEA) analysis. These efficiency scores were computed using 
the variable returns to scale (VRS) approach. The VRS approach allows for the computation eliminating calculation of technical efficiency (TE) further, using input-oriented BCC models, super efficiency scores were computed for 120 branches and were ranked according to efficiency scores.

\subsection{Measurement of variables}

\section{High-Performance Work Systems and unitary index}

There has been little agreement as to what constitutes HPWS (Lepak, Liao, Chung, \& Harden, 2006). Organizations have specific objectives and connecting them to the design of HPWS might present better insights into the effectiveness of HPWS (Lepak et al., 2006). Therefore, for this study, influential studies and its relevance to the study settings were identified which have focused on the effects of high-performance work practices on performance as an inclusion criterion in HPWS. These practices include JS, T\&D, employee participation, JD, information sharing, contingent compensation, and appraisal. These practices were measured with validated scales (Delery \& Doty, 1996; Zacharatos et al., 2005; Scott \& James, 1992) on a 5-point Likert scale.

The study adopted a widely used additive approach, which is consistent with one of the main principles of strategic human resource management that the effects of practices is better understood by testing the system of high-performance work practices (Huselid, 1995; Ostroff $\&$ Bowen, 2000; Lepak et al., 2006). Following the subscale aggregation additive approach, seven HR practices were aggregated into a unitary index that measures HPWS (Macky \& Boxall, 2007). An additive approach is also more appropriate for the present study model that assumes each practice is equally important within the HPWS index (Gittell et al., 2010). Relational Coordination: A seven items RC survey, developed by Gittell et al. (2010) was adapted for measuring relational coordination. The RC survey has been used to determine cross-functional as well as cross-organizational coordination among employees working in highly interdependent work settings.

\section{Branch performance measures}

To measure the branch performance of a bank, Paradi et al. (2011) proposed a production, intermediation, and profitability approach. Using Paradi's approach, selected branches are analysed about efficiency, liquidity, capital adequacy, and profitability. An identical set of unitlevel performance measures comprising deposits, lending, and profit were gathered across one hundred and twenty bank branches.

\section{Sampling and data collection procedure}

This study has been conducted in one of the largest and pioneer banks in Pakistan with a nationwide branch network of more than 1300 branches. Considering the distinct geographical location of the bank, 
the study considered 755 branches operating and located in the major provinces of Punjab, Khyber, and federal capital.

\section{Table 1: Sampled bank branches}

\begin{tabular}{lcccc}
\hline & The Punjab & Federal capital & KP & Total \\
\hline Branches & 360 & 190 & 205 & 755 \\
Surveyed & 155 & 78 & 107 & 340 \\
HPWS and RC & 58 & 68 & 92 & 218 \\
Matched Branches & 38 & 49 & 33 & 120 \\
\hline
\end{tabular}

In total, 3400 questionnaires were personally administered in the survey in 218 branches. The survey was sponsored by research funding. Participants completed 1830, of which only 1560 were usable. The sample characteristics of the respondents suggested that most of the employees are young professionals in the range of 31 to 40 years and mostly holding master's in business administration (MBA) qualifications with 5 to 10 years of experience in the banking sector.

\section{Instrument reliability and validity}

This study used validated scales with minor modifications and was evaluated and assessed in the context of reliability and validity. In the first step, an exploratory factor analysis (EFA) was conducted for HPWS and relational coordination. The factor loading of the items indicated the presence of strong loadings of all variables on only one component. Reliability was estimated using a common technique of Cronbach alpha coefficient and interrater reliability coefficients of ICC1 and ICC2 (LeBreton \& Senter, 2008). Validity is assessed in terms of interrater agreement (IRA) (see table 2). The alpha coefficient values for each scale, ICC1 and ICC2 were more than the recommended value justifying aggregation of HPWS and RC at a branch level. In terms of validity, the average values of interrater agreement rwg(j) of HPWS relational coordination for all functions exceed the recommended value of 0.70 (LeBreton et al., 2003).

Table 2: Reliability and validity analysis for HPWS and RC

\begin{tabular}{lccccc}
\hline Departments & ICC1 & ICC2 & $\begin{array}{c}\text { Intraclass } \\
(1)\end{array}$ & $\begin{array}{c}\text { Intraclass } \\
(2)\end{array}$ & $\begin{array}{c}\text { Interrater } \\
\text { Agreement }\end{array}$ \\
\hline & Two-way & & One-way & & rwgj \\
HPWS
\end{tabular}


Table 2a: Rotated component matrix for HPWS

\begin{tabular}{|c|c|c|c|c|c|c|c|c|}
\hline \multicolumn{9}{|c|}{ Components } \\
\hline Practices & Items & 1 & 2 & 3 & 4 & 5 & 6 & 7 \\
\hline \multirow{5}{*}{$\begin{array}{l}\text { Performance } \\
\text { appraisal }\end{array}$} & Q25 & .787 & & & & & & \\
\hline & Q27 & .767 & & & & & & \\
\hline & Q26 & .741 & & & & & & \\
\hline & Q28 & .700 & & & & & & \\
\hline & Q29 & .651 & & & & & & \\
\hline \multirow{4}{*}{$\begin{array}{l}\text { Employee } \\
\text { participation }\end{array}$} & Q10 & & .813 & & & & & \\
\hline & Q9 & & .738 & & & & & \\
\hline & Q11 & & .722 & & & & & \\
\hline & Q12 & & .651 & & & & & \\
\hline \multirow{4}{*}{$\begin{array}{l}\text { Extensive } \\
\text { training }\end{array}$} & Q7 & & & .779 & & & & \\
\hline & Q5 & & & .712 & & & & \\
\hline & Q8 & & & .704 & & & & \\
\hline & Q6 & & & 609 & & & & \\
\hline \multirow{3}{*}{ Role clarity } & Q14 & & & & .804 & & & \\
\hline & Q15 & & & & .772 & & & \\
\hline & Q13 & & & & .770 & & & \\
\hline \multirow{3}{*}{$\begin{array}{l}\text { Information } \\
\text { sharing }\end{array}$} & Q19 & & & & & .730 & & \\
\hline & Q17 & & & & & .708 & & \\
\hline & Q20 & & & & & .624 & & \\
\hline \multirow{4}{*}{ Job security } & Q2 & & & & & & .729 & \\
\hline & Q3 & & & & & & .722 & \\
\hline & Q4 & & & & & & .569 & \\
\hline & Q1 & & & & & & .520 & \\
\hline Performance & Q21 & & & & & & & .751 \\
\hline based & Q22 & & & & & & & .645 \\
\hline compensation & Q23 & & & & & & & .606 \\
\hline
\end{tabular}

Table 2b: Component matrix for relational coordination

\begin{tabular}{lc}
\hline & Component \\
\hline Items & Factor Loading \\
\hline Accurately & .785 \\
Timely & .746 \\
Problem Solving & .732 \\
Shared Goals & .726 \\
Frequently & .713 \\
Respect & .703 \\
Shared Knowledge & .688 \\
\hline
\end{tabular}

\section{Results and discussion}

The study is determined to measure the extent to which HPWS can predict the degree of relational coordination; to examine whether there is a positive relationship between the HPWS and firm performance in the banking sector of Pakistan. Data is analyzed using data envelopment analysis (DEA) technique to identify the most efficient branches in terms of their 
inputs and output efficiencies for 120 branches. These branches were analyzed through a widely used DEA for the financial efficiency of decision-making units (DMU). DEA is set up to measure the financial efficiency of units with several inputs and outputs (Gutierrez \& Goitisolo Lezama, 2011).

To examine the effects of HPWS on relational coordination and performance outcomes, DEA efficiency scores were calculated through HPWS as input for relational coordination and performance outcomes using BCC (Banker, Charnes, \& Cooper, 1984) input-based models. These inputs and outputs serve an exclusive combination to report the causes of either efficiency or inefficiency for each branch.

Tables 3, 4, and 5 provide efficiency scores for 120 branches among the inputs and outputs. Based on the model of Cinca and Molinero (2004), this study calculated DEA efficiency scores for three combinations. Firstly, to estimate the effects of HPWS in predicting relational coordination among employees (HPWS as input and relational coordination as output), secondly, to assess the relationship of HPWS with branch level performance outcomes (HPWS as inputs and performance outcomes as outputs), and thirdly, the effects of relational coordination on performance outcomes (RC as inputs and performance as outputs). Finally, for all three combinations, DEA super efficiency scores were computed to rank the efficient branches (Lovell \& Rouse, 2003). Table 6 presents the ranking of branches in terms of superefficiency scores. The maximum score of an efficient branch is 1suggesting that the branch is fully efficient to convert inputs into outputs. Branches that are less than 1 are considered inefficient branches on transforming inputs into outputs (Charnes, Cooper, \& Rhodes, 1978). Concerning the effects of HPWS in predicting relational coordination among employees, shown in Table 3, 4 out of 120 branches were 100 percent efficient. These branches include DMU number 58, 109, 102, and 116. Similarly, in terms of HPWs and its effects on performance, shown in Table 4, 6 out of 120 branches were fully efficient. A group of these 100 percent efficient branches comprises DMU 115, 101, 38, 103, and 33 respectively. Besides, regarding the effects of relational coordination on performance outcomes, shown in table 5, a total of 6 out of 120 branches were found 100 percent efficient in terms of RC as inputs and performance as outputs. Among full efficient branches, include DMU number 115, 103, 101, 38, 33, 45, 3, 109, and 15 .

Results shown in Tables suggest that DEA efficiency scores of branches vary across a combination of inputs and outputs. Several branches were efficient in several combinations. For instance, DMU such as 33, 38, 101, 105, and 109 are efficient branches in terms of using HPWS-performance relationships and relational coordination to performance relationships. These findings are consistent with numerous previous studies that examined the linkages and found that HPWS is positively related to firm performance (e.g. Siddique et al., 2019; Liao et al., 2009; Gittell et al., 2010). Together, these results contribute to the current understating of the linkages between HPWS and organizational performance in the service context. This study 
emphasizes the central role of relational coordination among employees as a meaningful element in the relationships between HPWS and performance.

Table 3: Super efficiency of branches on BCC input oriented models HPWS-RC

\begin{tabular}{|c|c|c|c|c|c|c|c|}
\hline DMU & $\begin{array}{c}\text { VRS Efficiency } \\
\text { Score }\end{array}$ & DMU & $\begin{array}{l}\text { VRS Efficiency } \\
\text { Score }\end{array}$ & DMU & $\begin{array}{l}\text { VRS Efficiency } \\
\text { Score }\end{array}$ & DMU & $\begin{array}{c}\text { VRS Efficiency } \\
\text { Score }\end{array}$ \\
\hline 1 & 0.56 & 31 & 0.32 & 61 & 0.46 & 91 & 0.67 \\
\hline 2 & 0.41 & 32 & 0.49 & 62 & 0.53 & 92 & 0.56 \\
\hline 3 & 0.45 & 33 & 0.58 & 63 & 0.62 & 93 & 0.73 \\
\hline 4 & 0.43 & 34 & 0.54 & 64 & 0.72 & 94 & 0.68 \\
\hline 5 & 0.71 & 35 & 0.55 & 65 & 0.58 & 95 & 0.62 \\
\hline 6 & 0.58 & 36 & 0.63 & 66 & 0.61 & 96 & 0.51 \\
\hline 7 & 0.42 & 37 & 0.42 & 67 & 0.56 & 97 & 0.84 \\
\hline 8 & 0.67 & 38 & 0.50 & 68 & 0.34 & 98 & 0.55 \\
\hline 9 & 0.48 & 39 & 0.43 & 69 & 0.39 & 99 & 0.72 \\
\hline 10 & 0.45 & 40 & 0.46 & 70 & 0.55 & 100 & 0.37 \\
\hline 11 & 0.57 & 41 & 0.36 & 71 & 0.52 & 101 & 0.39 \\
\hline 12 & 0.47 & 42 & 0.32 & 72 & 0.52 & 102 & 1.00 \\
\hline 13 & 0.47 & 43 & 0.42 & 73 & 0.57 & 103 & 0.83 \\
\hline 14 & 0.57 & 44 & 0.49 & 74 & 0.45 & 104 & 0.56 \\
\hline 15 & 0.63 & 45 & 0.52 & 75 & 0.70 & 105 & 0.49 \\
\hline 16 & 0.42 & 46 & 0.35 & 76 & 0.73 & 106 & 0.63 \\
\hline 17 & 0.50 & 47 & 0.52 & 77 & 0.57 & 107 & 0.63 \\
\hline 18 & 0.48 & 48 & 0.54 & 78 & 0.52 & 108 & 0.70 \\
\hline 19 & 0.44 & 49 & 0.63 & 79 & 0.62 & 109 & 1.00 \\
\hline 20 & 0.61 & 50 & 0.52 & 80 & 0.44 & 110 & 0.60 \\
\hline 21 & 0.47 & 51 & 0.60 & 81 & 0.44 & 111 & 0.74 \\
\hline 22 & 0.52 & 52 & 0.69 & 82 & 0.57 & 112 & 0.53 \\
\hline 23 & 0.57 & 53 & 0.56 & 83 & 0.42 & 113 & 0.56 \\
\hline 24 & 0.67 & 54 & 0.44 & 84 & 0.44 & 114 & 0.51 \\
\hline 25 & 0.58 & 55 & 0.62 & 85 & 0.49 & 115 & 0.71 \\
\hline 26 & 0.50 & 56 & 0.66 & 86 & 0.52 & 116 & 1.00 \\
\hline 27 & 0.40 & 57 & 0.50 & 87 & 0.56 & 117 & 0.43 \\
\hline 28 & 0.65 & 58 & 1.00 & 88 & 0.58 & 118 & 0.58 \\
\hline 29 & 0.60 & 59 & 0.44 & 89 & 0.54 & 119 & 0.83 \\
\hline 30 & 0.44 & 60 & 0.67 & 90 & 0.58 & 120 & 0.96 \\
\hline
\end{tabular}

Table 4. Super efficiency of branches on BCC input oriented models HPWSperformance

\begin{tabular}{cccccccc}
\hline DMU & $\begin{array}{c}\text { Efficiency } \\
\text { Score }\end{array}$ & DMU & $\begin{array}{c}\text { Efficiency } \\
\text { Score }\end{array}$ & DMU & $\begin{array}{c}\text { Efficiency } \\
\text { Score }\end{array}$ & DMU & $\begin{array}{c}\text { Efficiency } \\
\text { Score }\end{array}$ \\
\hline 1 & 0.45 & 31 & 0.29 & 61 & 0.34 & 91 & 0.76 \\
2 & 0.35 & 32 & 0.47 & 62 & 0.37 & 92 & 0.43 \\
3 & 0.46 & 33 & 1.00 & 63 & 0.53 & 93 & 0.46 \\
4 & 0.38 & 34 & 0.40 & 64 & 0.78 & 94 & 0.46 \\
5 & 0.61 & 35 & 0.38 & 65 & 0.45 & 95 & 0.83 \\
6 & 0.66 & 36 & 0.69 & 66 & 0.52 & 96 & 0.37 \\
7 & 0.27 & 37 & 0.33 & 67 & 0.45 & 97 & 0.89 \\
8 & 0.63 & 38 & 1.00 & 68 & 0.28 & 98 & 0.49 \\
9 & 0.56 & 39 & 0.40 & 69 & 0.34 & 99 & 0.58
\end{tabular}


Muhammad Siddique, Zahoor Khan \& Saleem Gul

\begin{tabular}{llllllll}
\hline 10 & 0.34 & 40 & 0.42 & 70 & 0.41 & 100 & 0.29 \\
11 & 0.68 & 41 & 0.27 & 71 & 0.40 & 101 & 1.00 \\
12 & 0.33 & 42 & 0.32 & 72 & 0.51 & 102 & 0.53 \\
13 & 0.41 & 43 & 0.36 & 73 & 0.38 & 103 & 1.00 \\
14 & 0.44 & 44 & 0.51 & 74 & 0.38 & 104 & 0.43 \\
15 & 0.69 & 45 & 0.96 & 75 & 0.40 & 105 & 0.45 \\
16 & 0.40 & 46 & 0.30 & 76 & 0.55 & 106 & 0.48 \\
17 & 0.46 & 47 & 0.43 & 77 & 0.56 & 107 & 0.43 \\
18 & 0.34 & 48 & 0.34 & 78 & 0.37 & 108 & 0.59 \\
19 & 0.38 & 49 & 0.39 & 79 & 0.43 & 109 & 1.00 \\
20 & 0.47 & 50 & 0.32 & 80 & 0.31 & 110 & 0.57 \\
21 & 0.33 & 51 & 0.39 & 81 & 0.31 & 111 & 0.59 \\
22 & 0.38 & 52 & 0.46 & 82 & 0.39 & 112 & 0.34 \\
23 & 0.37 & 53 & 0.43 & 83 & 0.42 & 113 & 0.43 \\
24 & 0.52 & 54 & 0.31 & 84 & 0.38 & 114 & 0.42 \\
25 & 0.41 & 55 & 0.70 & 85 & 0.46 & 115 & 1.00 \\
26 & 0.38 & 56 & 0.37 & 86 & 0.50 & 116 & 0.56 \\
27 & 0.32 & 57 & 0.34 & 87 & 0.32 & 117 & 0.35 \\
28 & 0.54 & 58 & 0.46 & 88 & 0.27 & 118 & 0.48 \\
29 & 0.75 & 59 & 0.29 & 89 & 0.27 & 119 & 0.58 \\
30 & 0.35 & 60 & 0.44 & 90 & 0.36 & 120 & 0.86 \\
\hline
\end{tabular}

Table 5: Super efficiency of branches on BCC input oriented models for RC-performance

\begin{tabular}{|c|c|c|c|c|c|c|c|}
\hline DMU & $\begin{array}{c}\text { VRS } \\
\text { Efficiency } \\
\text { Score } \\
\end{array}$ & DMU & $\begin{array}{c}\text { VRS Efficiency } \\
\text { Score }\end{array}$ & DMU & $\begin{array}{c}\text { VRS Efficiency } \\
\text { Score }\end{array}$ & DMU & $\begin{array}{c}\text { VRS Efficiency } \\
\text { Score }\end{array}$ \\
\hline 1 & 0.68 & 31 & 0.55 & 61 & 0.28 & 91 & 0.53 \\
\hline 2 & 0.51 & 32 & 0.54 & 62 & 0.25 & 92 & 0.40 \\
\hline 3 & 1.00 & 33 & 1.00 & 63 & 0.43 & 93 & 0.24 \\
\hline 4 & 0.36 & 34 & 0.30 & 64 & 0.63 & 94 & 0.26 \\
\hline 5 & 0.72 & 35 & 0.27 & 65 & 0.40 & 95 & 0.55 \\
\hline 6 & 0.44 & 36 & 0.45 & 66 & 0.38 & 96 & 0.28 \\
\hline 7 & 0.25 & 37 & 0.33 & 67 & 0.43 & 97 & 0.40 \\
\hline 8 & 0.36 & 38 & 1.00 & 68 & 0.41 & 98 & 0.36 \\
\hline 9 & 0.45 & 39 & 0.51 & 69 & 0.44 & 99 & 0.44 \\
\hline 10 & 0.31 & 40 & 0.80 & 70 & 0.37 & 100 & 0.39 \\
\hline 11 & 0.59 & 41 & 0.40 & 71 & 0.39 & 101 & 1.00 \\
\hline 12 & 0.28 & 42 & 0.90 & 72 & 0.55 & 102 & 0.16 \\
\hline 13 & 0.54 & 43 & 0.52 & 73 & 0.27 & 103 & 1.00 \\
\hline 14 & 0.57 & 44 & 0.59 & 74 & 0.50 & 104 & 0.37 \\
\hline 15 & 1.00 & 45 & 1.00 & 75 & 0.21 & 105 & 0.60 \\
\hline 16 & 0.77 & 46 & 0.47 & 76 & 0.28 & 106 & 0.33 \\
\hline 17 & 0.62 & 47 & 0.29 & 77 & 0.66 & 107 & 0.29 \\
\hline 18 & 0.28 & 48 & 0.26 & 78 & 0.34 & 108 & 0.35 \\
\hline 19 & 0.52 & 49 & 0.27 & 79 & 0.27 & 109 & 1.00 \\
\hline 20 & 0.38 & 50 & 0.22 & 80 & 0.32 & 110 & 0.39 \\
\hline 21 & 0.27 & 51 & 0.24 & 81 & 0.29 & 111 & 0.38 \\
\hline 22 & 0.32 & 52 & 0.22 & 82 & 0.23 & 112 & 0.36 \\
\hline 23 & 0.28 & 53 & 0.30 & 83 & 0.94 & 113 & 0.33 \\
\hline 24 & 0.34 & 54 & 0.29 & 84 & 0.63 & 114 & 0.41 \\
\hline 25 & 0.26 & 55 & 0.46 & 85 & 0.68 & 115 & 1.00 \\
\hline 26 & 0.30 & 56 & 0.22 & 86 & 0.43 & 116 & 0.22 \\
\hline
\end{tabular}


Journal of Applied Economics and Business Studies, Volume. 4, Issue 2 (2020) 163-180 https://doi.org/10.34260/jaebs.428

\begin{tabular}{llllllll}
\hline 27 & 0.46 & 57 & 0.27 & 87 & 0.18 & 117 & 0.39 \\
28 & 0.47 & 58 & 0.12 & 88 & 0.13 & 118 & 0.45 \\
29 & 0.48 & 59 & 0.28 & 89 & 0.15 & 119 & 0.27 \\
30 & 0.39 & 60 & 0.22 & 90 & 0.24 & 120 & 0.54 \\
\hline
\end{tabular}

Table 6: Ranking of efficient branches based on super efficiency

\begin{tabular}{ccccccccc}
\hline & HPWS-RC & \multicolumn{3}{c}{ HPWS-Performance } & \multicolumn{3}{c}{ RC-Performance } \\
\hline DMU & $\begin{array}{c}\text { Efficiency } \\
\text { Score }\end{array}$ & Rank & DMU & $\begin{array}{c}\text { Efficiency } \\
\text { Score }\end{array}$ & Rank & DMU & $\begin{array}{c}\text { Efficiency } \\
\text { Score }\end{array}$ & Rank \\
\hline 58 & 1.30 & 1 & 115 & 1.52 & 1 & 115 & 1.88 & 1 \\
109 & 1.23 & 2 & 101 & 1.47 & 2 & 103 & 1.86 & 2 \\
102 & 1.08 & 3 & 38 & 1.43 & 3 & 101 & 1.84 & 3 \\
116 & 1.00 & 4 & 103 & 1.40 & 4 & 38 & 1.80 & 4 \\
& & & 33 & 1.38 & 5 & 33 & 1.71 & 5 \\
& & & 109 & 1.26 & 6 & 45 & 1.61 & 6 \\
& & & & & & 3 & 1.51 & 7 \\
& & & & & & 109 & 1.18 & 8 \\
\hline
\end{tabular}

\section{Conclusion and implications}

This study was aimed to assess the effects of HPWS in predicting the degree of relational coordination among employees and improving the efficiency of unit-level performance in the banking service sector of Pakistan. The data obtained from officer cadre employees of 218 branches about HPWS and relational coordination and branch performance outcomes including deposits, advances, and profitability was analysed using DEA techniques for efficiency scores of bank branches in terms of the use of inputs in generating efficient output. The superefficiency scores were computed for analysing the effect of HPWS and relational coordination in improving the efficiency of branches. Using input-oriented BCC data envelopment analysis models, super efficiency scores were computed for 120 branches and the most efficient branches were ranked in terms of three combinations of input-output models including HPWSRC; HPWS-performance; and RC-performance.

The findings suggested that based on the combination of input-output, certain branches were more efficient on HPWS in predicting relational coordination among employees, while some branches were highly efficient on HPWS and relational coordination concerning performance outcomes of deposits, advances, and profitability. These results suggest that HPWS designed to foster relational coordination among employees will positively influence unit-level performance.

The study provides a new understanding of the linkages between HPWS and performance. It provides practical implications for policymakers suggesting the importance of employees' perspectives as the findings present an important indication that there was a relational process, whereby relational coordination was related to an extent of HPWS and its impact on unit-level performance outcomes. 


\section{References}

Adler, P., Kwon, S. \& Heckscher, C. (2008). The emergence of collaborative community, Organization Science, 19(2), 359-376.

Appelbaum, E., Bailey, T., Berg, P. \& Kalleberg, A. L. (2000). Manufacturing advantage: Why high-performance work systems pay off. Washington, D. C.: Economic Policy Institute.

Babbie, E. (2004). The Practice of Social Research, Wadsworth, Thomson Learning Inc.

Banker, R. D, Charnes, A, \& Cooper, W. (1984). Some models for estimating technical and scale inefficiencies in data envelopment analysis. Management science, 30(9), 10781092.

Bing, M., Guimei, M., Xiaolang L., \& Lassleben, H, (2020). Relationship between a highperformance work system and employee outcomes: A multilevel analysis. Social Behavior \& Personality: An International Journal, 48(1), 1-9.

Boon, C., Den Hartog, D., \& Lepak, D. (2019). A systematic review of human resource management systems and their measurement. Journal of Management, 45(6), 2498-37.

Boselie, P., Dietz, G. \& Boon, C. (2005). Commonalities and Contradictions in HRM and Performance Research, Human Resource Management Journal, 15(3), 67-94.

Bowen, D. E. \& Ostroff, C. (2004). Understanding HRM-firm performance linkages: The role of the strength of the HRM system'. Academy of Management Review, 29(2), 203-212.

Boxall, P. (2012). Building highly performing work systems: Analysing HR systems and their contribution to performance, In: Guest, D., Paauwe, J., and Wright, P. HRM and Performance: Achievements and challenges. Hoboken: Wiley, Hoboken. 108-133.

Chao, W., \& Chih-Ting, S. (2018). Customer service-focused HRM systems and firm performance: evidence from the service industry in Taiwan, The International Journal of Human Resource Management, 29(19), 2804-2826.

Charnes, A, Cooper, W, \& Rhodes, E. (1978). Measuring the efficiency of decision-making units. European Journal of Operational Research, 2(6), 429-444.

Cinca, C., Serrano, \& Molinero, C. (2004). Selecting DEA specifications and ranking units via PCA. Journal of the Operational Research Society, 55(5), 521-528.

Collins, C. J. \& Smith, K. G. (2006). Knowledge exchange and combinations: The role of HR practices in the performance of High-technology firms'. Academy of Management Journal, 49(3), 544-560.

Delery, J. \& Doty, D. (1996). Modes of theorizing in strategic human resource management. Academy of Management Journal, 39(4), 802-835. 
Dyer, L. \& Reeves, T. (1995). Human resource strategies and firm performance: What do we know and where do we need to go?, International Journal of Human Resource Management, 6(3), 656-670.

Faraj, S. \& Sproull, L. (2000). Coordinating expertise in software development teams, Management Science, 46(12), 1554-1568.

Fu, N., Bosak, J., Flood, P. C., \& Ma, Q. H. (2019). Chinese and Irish professional service firms compared: Linking HPWS, organizational coordination, and firm performance. Journal of Business Research, 95, 266-276.

Gerhart, B. (2012). Research on human resources and effectiveness: some methodological challenges, In: Guest, D., Paauwe, J., and Wright, P. HRM and Performance: Achievements and Challenges. Hoboken: Wiley, Hoboken.108-133.

Gittell, J. (2001). Supervisory span, relational coordination and flight departure performance. Organization Science, 12(4), 468-483.

Gittell, J. H. (2002). Coordinating mechanisms in care provider groups: Relational coordination as a mediator and input uncertainty as a moderator of performance effects, Management Science, 48(11), 1408-1426.

Gittell, J., Seidner, R. \& Wimbush, J. (2010). A relational model of how high performance work systems work. Organization Science, 21(2), 490-506.

Graham, L., Zheng, Y., Gracey, S., \& Plater, M. (2020). The Role of Managers' Values in the Relationship between High Performance Work Systems and Customer Satisfaction: A Team-Level Perspective. Available at SSRN: https://ssrn.com/abstract=3553721.

Guest, D. (1997). Human Resource Management and Performance: A Review and Research Agenda, International Journal of Human Resource Management, 8(3), 263-76.

Gutierrez, J., \& Goitisolo Lezama, B. (2011). Profitability and Social Performance of Microfinance Institutions: Empirical Evidence of Relations between Different Types of Variables. reviSta de economía mundial (27), 189-214.

Han, J. H., Bartol, K. M., \& Kim, S. (2015). Tightening up the performance-pay linkage: Roles of contingent reward leadership and profit-sharing in the cross-level influence of individual pay-for-performance. Journal of Applied Psychology, 100(2), 417-430.

Havens, D. S., Gittell, J. H., \& Vasey, J. (2018). Impact of relational coordination on nurse outcomes: Achieving the quadruple aim. Journal of Nursing Administration, 48(3), 132-140. 
Huselid, M. A. (1995). The impact of human resource management practices on turnover, productivity, and corporate financial performance, Academy of Management Journal, $38(3), 635-672$.

Karadas, G., \& Osman, M. Karatepe, (2019). Unravelling the black box: The linkage between high-performance work systems and employee outcomes, Employee Relations, 41(1), 67-83.

Kehoe, R. R., \& Collins, C. J. (2017). Human resource management and unit performance in knowledge-intensive work. Journal of Applied Psychology, 102, 1222-1236.

LeBreton, J., Burgess, J., Kaiser, R., Atchley, E., \& James, L. (2003). The restriction of variance hypothesis and interrater reliability and agreement. Organizational Research Methods, 6(1), 80-128.

LeBreton, M. J. \& Senter, L. J. (2008). Answers to 20 questions about interrater reliability and interrater agreement, Organizational Research Methods, 11(4), 815-835.

Lee, H. W., Pak, J., Kim, S., \& Li, L. Z. (2019). Effects of human resource management systems on employee proactivity and group innovation. Journal of Management, 45(2), 819-846.

Lepak, D., Liao, H., Chung, Y., \& Harden, E. (2006). A conceptual review of human resource management systems in strategic human resource management research. Research in Personnel and Human Resource Management, 25, 217-271.

Liao, H., Toya, K., Lepak, D. P. \& Hong, Y. (2009). Do they see eye to eye? Management and employee perspectives of high-performance work systems and influence processes on service quality, Journal of Applied Psychology, 94(2), 371-391.

Lovell, CAK, \& Rouse, APB. (2003). Equivalent standard DEA models to provide superefficiency scores. Journal of the Operational Research Society, 54(1), 101-108.

Macky, K. \& Boxall, P. (2007). The relationship between high performance work practices and employee attitudes: an investigation of additive and interaction effects. International Journal of Human Resource Management, 18(4), 537-567.

Malhotra, P., \& Singh, M. (2016). Indirect impact of high performers on the career advancement of their subordinates. Human Resource Management Review, 26(3), 209226.

Methot, J. R., Melwani, S., \& Rothman, N. B. (2017). The space between us: A socialfunctional emotions view of ambivalent and indifferent workplace relationships. Journal of Management, 43(6), 1789-1819. 
Methot, J. R., Rosado-Solomon, E. H., \& Allen, D. G. (2018). The network architecture of human capital: A relational identity perspective. Academy of Management Review, 43(4), 723-748.

Meuer, J. (2017). Exploring the complementarities within high-performance work systems: A set theoretic analysis of U.K. firms. Human Resource Management, 56(4), 651-672.

Mingqiong, Z., Cherrie, J, Dowling, P., \& Bartram, T. (2013). Exploring the effects of highperformance work systems (HPWS) on the work-related well-being of Chinese hospital employees, The International Journal of Human Resource Management, 24(16), 31963212.

Murphy, K., Torres, E., Ingram, \& Hutchinson, J. (2018). A review of high performance work practices (HPWPs) literature and recommendations for future research in the hospitality industry. International Journal of Contemporary Hospitality Management, 30(1), 365388.

Nien-Chi Liu \& Yi-Ting Lin (2019): High-performance work systems, management team flexibility, employee flexibility and service-oriented organizational citizenship behaviours, The International Journal of Human Resource Management, DOI: 10.1080/09585192.2019.1651374

Ogbonnaya, C., \& Valizade, D. (2018). High performance work practices, employee outcomes and organizational performance: A 2-1-2 multilevel mediation analysis. The International Journal of Human Resource Management, 29(2), 239-259.

Ostroff, C. \& Bowen, D. (2000). Moving HR to a higher level: HR practices and organizational effectiveness. In Klein KJ, Kozlowski SWJ (eds). Multilevel theory, research, and methods in organizations: foundations, extensions, and new direction. San Francisco, CA: Jossey-Bass; 211-67.

Paauwe, J., Wright, P. \& Guest, D. (2012). HRM and performance: what do we know and where should we go? In: Guest, D., Paauwe, J., \&Wright, P. HRM and Performance: Achievements \& challenges. Hoboken: Wiley, Hoboken. 28-53.

Paradi, J.C., Yang, Z. \& Zhu, H. (2011). Assessing Bank and Bank Branch Performance Modelling Considerations and Approaches' in Handbook on Data Envelopment Analysis International Series in Operations Research and Management Science, 164, 315-361.

Pfeffer, J. (1998). The Human Equation: Building Profits By Putting People First. Boston: Harvard Business School Press.

Romanow, D. S., Rai, A., \& Keil, M. (2018). CPOE-enabled coordination: Appropriation for deep structure use and impacts on patient outcomes. MIS Quarterly, 42(1), 189-212. 
Russell, Z. A., Steffensen, D. S., Ellen, B. P., Zhang, L., Bishoff, J. D., \& Ferris, G. R. (2018). High performance work practice implementation and employee impressions of line manager leadership. Human Resource Management Review, 28(3), 258-270.

Scott, A. S. \& James, W. D. (1992). Integrated manufacturing and human resource management: A human capital perspective'. The Academy of Management Journal, 35(3), 467-504.

Siddique, M., Procter, S. \& Gittell, J. (2019). The role of relational coordination in the relationship between high-performance work systems (HPWS) and organizational performance, Journal of Organizational Effectiveness: People and Performance, 6(4), 246-266.

Sun, J.-M., Xing, L., Yin, K., \& Yang, Y. (2018). When does high performance work system increase employees' well-being? The role of core self-evaluation and need for achievement. Journal of Capital University of Economics and Business, 20(6), 44-53.

Wright, P., \& Ulrich, M. (2017). A road well-traveled: The past, present and future journey of strategic human resource management. Annual Review of Organizational Psychology and Organizational Behavior, 4, 45-65.

Zacharatos, A., Barling, J., \& Iverson, R. (2005). High-performance work systems and occupational safety. Journal of Applied Psychology, 90(1), 77-93. 